\title{
Bacha Posh: A Study of The Micronarratives of Gender in Afghanistan
}

\author{
Pauline Lalthlamuanpuii ${ }^{1} \&$ Suchi $^{2}$ \\ ${ }^{1}$ Research Scholar, National Institute of Technology Mizoram. \\ Email:poehmar@gmail.com \\ ${ }^{2}$ Assistant Professor, Research Scholar, National Institute of Technology Mizoram
}

\begin{abstract}
The blitzkrieg destabilization of Afghanistan by major world powers and factional groups in contemporary times has triggered major academic works on the country. One witnessed a surge in interest and curiosity about the socio-cultural, religious, political, and economic dynamics of the country. Often regarded as one of the most unsafe country for women in the world, this paper will focus on the concept of a bacha posh in Afghanistan. A bacha posh is a Dari word for a girl disguised as a boy. This paper attempts to examine the power structures that 'created' a bacha posh in Afghanistan. The idea of a bacha posh in Afghanistan is a "performativity", shaped by dialogues that moves beyond the "normative" gender binaries of male and female. A bacha posh move beyond the grand totalizing narratives of gender binaries to create a space that marked by fluidity and freedom. Even though the identity of a bacha posh is a shared deceit, created to serve the needs of an androcentric society, one cannot ignore its subversive nature. A bacha posh subverts the dictums of patriarchy by allowing the girl- child to re-define her subalternity. What happens if the realization of her subalternity results, not in striving for acceptance in the dominant framework of knowledge from which she is excluded, but in the establishment of an alternative centre?
\end{abstract}

Keywords- bacha posh, resistance, subaltern, identity, woman, Afghanistan, empowerment, micronarratives, performativity.

\section{Introduction}

A bacha posh is a Dari word which literally means "dressed as a boy". The term was first introduced in the book The Underground Girls of Kabul. The Hidden Lives of Afghan Girls Disguised as Boys by Jenny Nordberg. In the book, Nordberg investigates the secret lives of a bacha posh. It is indeed appalling to discover that even though it is a system that is widely practised in Afghanistan, most people are reluctant to admit it or even talk about its existence. But Nordberg's studies reveal that it is indeed very much part of the everyday reality in Afghanistan. "The bacha posh tradition is not rooted in religion, but rather in the cultures of Afghanistan and neighbouring Pakistan. There are theories that it came from a need for boys or men to fight in times of war but evolved to fill a different "void". It's not happening in every household, but nearly every Afghan I've spoken to knew of a bacha posh in his or her neighbourhood" (Nordberg, 2014, p. 5). The bacha posh tradition is practised by families without a male-child. In a society where patrilineal and tribal lineage holds more authority than any form

(C) AesthetixMS 2020. This Open Access article is published under a Creative Commons Attribution Non-Commercial 4.o International License (http://creativecommons.org/licenses/by-nc/4.o/), which permits non-commercial re-use, distribution, and reproduction in any medium, provided the original work is properly cited. For citation use the DOI. For commercial re-use, please contact editor@rupkatha.com. 
of governance, a bacha posh fits into the "informal structures" or the micronarratives of Afghan society. The "informal structures" are the system of knowledge shared by Afghan women. What goes on in the private lives of Afghan women, the desperation for a son is best understood by other women and midwives, not foreign scholars or Afghan men. The bacha posh is one of those 'informal structures', that part of gender roles not mentioned in the hegemonic structures of Afghan society. The life of a bacha posh is deeply intertwined with the histories of women in Afghanistan; the ones that are silenced and accepted.

I locate them through Kabul's plentiful maze of gossip, where firsthand information is rarely offered up at once, and only in face- to- face meetings...officially they do not exist, but one degree beyond the foreign educated Kabul elite, many Afghans can indeed recall a former neighbour, a relative, a colleague, or someone in their extended family with a daughter growing up as a boy. At first, there are rarely names, and never by way of address. But the wealth of human knowledge embedded in a system of tight social control stands in place of a phone book, a database, and a map. (Nordberg, 2014, p. 66)

In Afghanistan, the pressure to bear a male child is not only perpetuated by the men. It is also perpetuated by women as well. "Families can be rich, poor, educated, uneducated, Pashtuns, Tajiks, Hazara or Turkoman- it doesn't matter, they tell me. The only thing that binds the girls together is their family's need for a son (Nordberg,2014, p. 70). Much of the need for a male child is driven by the need for security and economic reasons in the conflict - torn country. A male child symbolizes power and protection. "There is no social security, little health care and virtually no rule of law in Afghanistan. There is just unemployment, poverty and constant war. In this environment, the number of sons equals a family's strength.... They are insurance (Nordberg, 2014, p. 44)." It is a signifier of continuity and prosperity while a female child is never considered a part of the family. A female child is a property, a commodity to be passed from one male to another. A woman's worth and standing in Afghan society is largely determined by her ability to bear a male child.

A baby boy is triumph, success. A baby girl is humiliation, failure. He is a bacha, the word for child. A boy. She is the "other", a dokhtar. A daughter.

The woman who returns home with a son can be celebrated with a nashrah ceremony, where music is played and prayers are said. Food and drinks will be brought out in abundance. The new mother will be presented with gifts: a dozen chickens or a goat to celebrate her achievement...she is elevated to a higher status among women. She who can deliver sons is a successful, enviable woman; she represents both good luck and a good wife. (Nordberg, 2014, p. 40).

\section{Created Identity}

A bacha posh is found all over Afghanistan. Even though they are never mentioned in the official narratives, a close study of the everyday realities reveals the important role a bacha posh fulfilled in Afghan society. A bacha posh is found in all walks of life. She cuts across the urban -rural divide. A bacha posh cuts across all economic sections as well. She is expected to fill a 'lack' in Afghan society-the lack of a boy child. A bacha posh is someone who is created for the convenience of the androcentric society. She enables the smooth functioning of a society that is conflict-ridden. 
A bacha posh is a desire-fulfilling entity both for men and women in Afghan society. She compensates for her parent's inability to produce a male heir. She also acts on behalf of a disabled father by assuming the roles of a boy/man. By donning boy-clothes she 'qualifies' her mother to become a 'real' woman- a woman who bears a male child. In Afghanistan, the idea of motherhood is strongly determined by the ability to produce sons. So, a bacha posh becomes a legitimizing factor for both her parents. She gave them a sense of identity and dignity in a society where one's identity is legitimized by the ability to bear sons.

A bacha posh can be found across all sections of Afghan society. "Although none of the girls chose their boyhood voluntarily, most say they enjoyed their borrowed status. It all depends on what they get to do with it. For each child, it boils down to perks versus burdens". (Nordberg,2014, p. 67). A bacha posh from an upper- class or middle-class family may enjoy her status as it entails access to male -privileges that were otherwise denied to her. A bacha posh from a well-to-do family is indulged fondly. Mehran, a bacha posh from an affluent family in Kabul, is envied by her sisters. For Mehran, being a bacha posh is liberating as it entails no economic burden. Mehran quickly learned how to 'exploit' her privileges as a boy.

On the other hand, for a girl like Niima who hails from the poorest sections of the society, being a bacha posh is simply a matter of survival for the family. Niima's father, an opium addict, is unable to provide for his family. In a society where the concept of a woman working outside of the home is frowned upon, a bacha posh seems to be the only viable solution. At the suggestions of a kind, elderly neighbor Niima is quietly 'changed' into a boy. It is a convenient arrangement as she could now earn for the family survival, "Niima poses as a boy purely for the survival of her family. There is nothing voluntary about it and her act hardly contains an element of freedom" (Nordberg,2014, p. 63). For most bacha posh, the role proves to be burdensome. it is just a system where the role of the father is passed on to them, at a very tender age. They are forced to become the breadwinner for the family. In this context, a bacha posh is just another form of child labor. The girl-child is robbed of her childhood to fulfill the needs of her family. Poverty, hunger, and the needs of daily livings are the factors that shape the identity of a bacha posh amongst the poorer sections of Afghan society. Families like Niima's have a well-planned system in place where a younger daughter will take up the role of a bacha posh, once the elder daughter hits puberty. It is a system which subtly subverts the androcentric, patriarchal system that only allows men to work on the public sphere. The bacha posh here empowers the helpless mother by creating a system where her needs are met, indirectly.

Jenny Nordberg in The Underground Girls of Kabul. The Hidden Lives of Afghan Girls Disguised as Boys tells the story of Subhnum, a bacha posh. Her transition to a bacha posh is not driven by a need for a boy child. Subhnam's mother Nahid has one son but she is dictated by circumstances to change her daughter into a boy. As a victim of constant abuse from her husband, Nahid dares to walk away from her marriage and fend for herself:

But as a single mother of three- which is almost unheard of in Kabul- she had to balance her family with an extra son, for them all to feel safer.

As a woman with two sons, however, she is considered a slightly more respectable creature. (Nordberg, 2014. p. 65)

A single mother with more sons is respected. A single woman or a divorced woman is stigmatized in Afghan society. A woman's respectability and honor are strictly defined by her relationship to men. In a society where the idea of maleness seems to be synonymous with respectability, Nahid 
subverts the harsh patriarchal codes of conduct by 'changing' her daughter into a boy. It is driven by a need for security.

Zarhuna Kargar's Dear Zari. Hidden Stories from Women in Afghanistan is a collection of real-life stories of women in Afghanistan. The stories are narrated by the women themselves. "Bakhtawara's Story. The Boy-Girl" narrates the story of Bakhtawara, a bacha posh. Bakhtawara's story is narrated by herself for B.B. C's special program titled "Afghan Women's Hour". Bakhtawara's story is a testament to the inherent contradictions that a bacha posh is. Her life is scarred by the power struggles in her society. Her body is a playground, trampled upon. Her identity is forced upon her while her desires are silenced.

Bakhtawara's life is a testament to the practice of the concept of a bacha posh in Afghanistan. "The society she lives in has taken away her right to live as a woman: yet on the other hand she has gained a kind of freedom no other Afghan woman could ever hope to attain" (Kargar, 2012, p. 224). She is forced by her family to abandon her identity as a woman. A simple act of "dressing her as a boy" is all it takes to rob her of her identity. She is expected to fulfil her father's desire for a male child simply by giving up her own identity and desires. "Her parents didn't stop to consider what harm this might do to their child, they just started to treat her as their second son" (Kargar ,2012. P. 230).

Bakhtawara's transformation to a bacha posh is fuelled by the need for security and a male heir in a feudalistic Pashtun society where a male child symbolizes security and economic prosperity. Her father handed her his gun and Bakhtawara understood the gravity of the act. In Afghan culture 'being handed,' a gun symbolizes a transference of power and responsibilities. It implies that Bakhtawara, as a man, is now solely responsible for the safety and honor of the family. For a Pashtun, honor is everything. Families have torn apart in the name of honor. Crimes are committed in the name of honor. Women are murdered, punished, and maimed in the name of honor.

Everyone in the village is aware of Bakhtawara's true identity. Her identity is a shared deceit, "She was respected for fulfilling her parent's wishes and taking on the responsibility of the head of the family" (Kargar, 2012, p. 232). The identity of a bacha posh implies tacit approvals from all sections of the society. Her 'created identity' is an identity that is sanctioned by the hegemonic patriarchal discourse. Yet, being a bacha posh gave her freedom unimaginable as a woman. Bakhtawara could take part in the administrative reforms of her village as a member of the jirgah (traditional assembly of male leaders). Her identity as a bacha posh gave her voice in the political arena. Being a bacha posh entails, "freer than other women. She didn't have to suffer domestic violence; she could meet men in public and they respected her. She was in charge of her own life. There was no one to tell her what to do. She worked hard and had money of her own, which she could spend as she liked." (Kargar, 2012, p. 240).

Even though her new identity as a man liberates her from certain roles and obligations, one is painfully aware of her 'silence' in forging her identity. The patriarchal Pashtun society demands silence and conformity to perpetuate its hegemonic notion of family and society. The concept of honor centered on the Pashtun ideas of masculinity must be preserved at all costs. The honor of the father, the husband, the brother, and the son are always paramount and unnegotiable. Afghan women continue to bear the brunt of outdated concept of masculinity and honor, "'if you look after the family well,' her father said, 'our honor will remain and you will keep my name alive"' (Kargar,2012, p. 232). 
The life of a bacha posh is characterized by fluidity and seamlessness. Bakhtawara's life story is marked by the fluidity of gender roles. Indeed, a bacha posh functions as an intermediary between male and female sexes in Afghan society. Between the extreme polarities of male and female with its rigid roles imposed by the androcentric society, the bacha posh is the 'hybrid' space. It is a space sanctioned and created by the society to fulfil the needs of patriarchy. As a bacha posh, Bakhtawara gains access to the intimate lives of both sexes. Forced by society to change her sex and identity, Bakhtawara is the voice of an outsider. Her worldviews are shaped by a deep internalization as well as critical knowledge of the androcentric social structures that shaped Afghan society. "Bakhtawara knew the harsh realities of both worlds: the world of the man and the feelings of the woman- she had experienced both." (Kargar,2012, p. 241).

\section{Clothes and Subversion}

Clothing in Afghanistan symbolizes power. Clothing symbolizes mobility for women in Afghanistan. Women's mobility is determined by the presence of mahram (male relatives) and how she is dressed up. Women's bodies must be covered up in public. This practice is called chaddari. The different forms of chaddari however share a commonality as a manifestation of power in Afghan society. Women's bodies must be covered, controlled, and subjugated in the name of honor. A succession of regimes in Afghanistan has always dictated clothing in the public arena, from religious hardliners dictating how women dress to the first world neo-imperialist powers claim to liberate Afghan women by removing her chaddari.

Clothing has always been a medium to communicate class, gender, and power. In Afghanistan, gender and power are the same. "A pair of pants, a haircut, the right walk, and a teenage girl can reach for all kinds of things she is not supposed to have. Just as the Taliban strictly controlled how both men and women looked during their reign- when women could appear in public only when covered from head to toe- specific rules on clothing have been used throughout history by those who want to make sure the patriarchal order stays in place" (Nordberg,2014, p. 90). It is in this context that the idea of a bacha posh, a girl dressed as a boy acquires new meanings. It becomes subversive. Judith Butler in Gender Trouble (1990) states that gender is performative. She states that the performativity of gender is a repetition of acts, an imitation of the dominant heterosexual act or norms. A bacha posh is someone whose identity is chosen for her! She is a female 'veiled' in male clothing. She is sanctioned by society to 'act repetitively' like a boy. The simple act of 'dressing up' as a boy acquires a new political and sociological significance in the context of Afghanistan.

The bacha posh in the context of Afghanistan is complicated and subversive. A bacha posh subverts narratives of hegemonic gender and patriarchal discourse by re-creating her own center. A center that is subversive and pragmatic. A bacha posh moves away from the discourse of androcentric Pashtunwali to create micronarratives of gender that is more accommodating and liberating for women in Afghanistan. A simple change in fashion or clothing opens up a whole new arena of dialogues and power. It opens up space to re-define the terms of their subalternity. It allows her to venture in to arenas that are otherwise restricted to women. A bacha posh defies grand totalizing narratives of gender, logic and science. A bacha posh cannot fit into the totalizing narratives of gender and gender roles. Its contradictory nature makes it subversive in nature, "I do think that for a copy to be subversive of heterosexual hegemony it has to both mime and displace its conventions". ("Judith Butler and Performativity", 2020) 


\section{Conclusion}

So much has been written on Afghan women in the last ten years and yet so little is known about who they are, what they need or what they want. Dominant (specifically Western) scholarship on Afghan women, often speaks about them, with the assertion that they are representing 'authentic' voices and experiences of Afghan women. These women are portrayed as silent and passive victims of their culture, their men and their politics. Sometimes we are introduced to an extraordinary Afghan woman who defies her culture and becomes a symbol of hope and progress for advancing women's rights in Afghanistan. The voices lacking in this scholarship are those of the everyday woman, the one who have survived decades of war, who continue to find ways to meet the needs of her family and is still finding ways to survive under escalating poverty, insecurity and patriarchal oppression. Although these women have always faced multiple economic, social and political invasions they have never been passive or silent. Rather they have been fighting for their rights long before the West invaded Afghanistan. Even in exile, Afghan women continue to empower themselves by constantly fighting stereotypes about their culture, their religion, and creating solidarity with other Afghan and Muslim women of diverse backgrounds. A bacha posh challenges stereotypes that are associated with Afghan women by opening up new challenges and dialogues that were otherwise swept under the complicated knots of the intrinsically woven Afghan society.

\section{WORKS CITED}

Ahmed, Leila. 2005. "The Discourse of the Veil”. Postcolonialism.An Anthology of Cultural Theory and Criticism. edited by Gaurav Desai and Supriya Nair, Oxford International Publishers Ltd.

---. 1992. Women and Gender in Islam. Roots of a Modern Debate. Yale University Press.

Barrett, Michelle. 1980. "Ideology and The Cultural Production of Gender". Women's Oppression Today: Problems in Marxist Feminist Analysis. London.

Butler, Judith. 1994. Gender Trouble. Routledge.

Bhabha, Homi K. 2017. Location of Culture. Routledge Classics.

Judith Butler and Performativity. 2020, September 14. http://artsites.ucsc.edu/faculty/gustafson/FILM\%20165A.

Kargar, Zarghuna. 2012. Dear Zari. Hidden Stories from Women in Afghanistan. Vintage Books.

Lewis, Reina. 1999. “On Veiling, Vision and Voyage”, On Veiling, Vision and Voyage: Cross-cultural Dressing and Narratives of Identity' Interventions 1:4,

Mohanty, Chandra Talpade. 20o6. "Under Western Eyes. Feminist Scholarship and Colonial Discourses". The Post-Colonial Studies Reader. edited by Bill Ashcroft, Gareth Griffiths and Helen Tiffin, Routledge.

Nordberg, Jenny. 2014. The Underground Girls of Kabul. The Hidden Lives of Afghan Girls Disguised as Boys. Virago Press.

Rostami -Povey, Elaheh. 2007. Afghan Women. Identity and Invasion. Zed Books.

Spivak, Gayatri. 2006. “Can the Subaltern Speak?”. The Post-Colonial Studies Reader. edited by Bill Ashcroft, Gareth Griffiths and Helen Tiffin, Routledge.

"Women’s Rights in Afghanistan”. 19 May,2019. http:// www.amnesty.org.uk. 